\title{
Frugivory by the White-bearded Manakin (Manacus manacus, Pipridae) in restinga forest, an ecosystem associated to the Atlantic forest
}

\author{
César Cestari ${ }^{1,2,3}$ \& Marco Aurélio Pizo ${ }^{2}$ \\ ${ }^{1}$ Programa de Pós-graduação em Zoologia, Universidade Estadual Paulista "Júlio de Mesquita \\ Filho"-UNESP, Av. 24A, 1515, Bela Vista, CEP 13506-900, Rio Claro, SP, Brasil \\ ${ }^{2}$ Departamento de Zoologia, Universidade Estadual Paulista “Júlio de Mesquita Filho" - UNESP, Av. 24A, \\ 1515, Bela Vista, CEP 13506-900, Rio Claro, SP, Brasil. http://www.rc.unesp.br/ib/zoologia \\ ${ }^{3}$ Corresponding author: César Cestari,e-mail: cesar_cestari@yahoo.com.br
}

CESTARI, C. \& PIZO, M.A. Frugivory by the White-bearded Manakin (Manacus manacus, Pipridae) in restinga forest, an ecosystem associated to the Atlantic forest. Biota Neotrop. 13(2): http://www.biotaneotropica. org.br/v13n2/en/abstract?short-communication+bn03813022013

Abstract: Manakins (Pipridae) are one of the most abundant fruit-eaters and seed dispersers in the understory of neotropical forests. We describe the fruit diet of the White-beaded Manakin (Manacus manacus) based on a two-year study of its foraging behavior on fruiting plants, collecting seeds from feces and regurgitations of trapped individuals, and from lekking males' courts in restinga forests at the southern coast of the state of São Paulo, Brazil. Manacus manacus consumed 58 species of fruits from 30 different plant families. Fruits were taken at $3.5 \pm 1.9 \mathrm{~m}$ height and $1.5 \pm 1.6 \mathrm{~m}$ below the forest canopy using mainly sally-strike and glean manoeuvres. Most of the fruits were berries ranging from 3.1 to $17 \mathrm{~mm}$ in diameter and containing from 1 to 86 seeds. Fruits up to $12 \mathrm{~mm}$ in diameter were swallowed whole. Ripe and unripe fruits were equally consumed. Our results corroborate with the great variety of small fruits consumed by manakin species, and indicate that M. manacus is an important seed disperser, potentially contributing to recruitment of plants in restinga.

Keywords: dispersion, fruits, animal-plant interaction, seeds.

CESTARI, C. \& PIZO, M.A. Frugivoria pela rendeira (Manacus manacus, Pipridae) em floresta de restinga, um ecossitema associado à Mata Atlântica. Biota Neotrop. 13(2): http://www.biotaneotropica.org.br/v13n2/pt/ abstract?short-communication+bn03813022013

Resumo: Os tangarás (Pipridae) são um dos grupos de aves frugívoras e dispersoras de sementes mais abundantes em estratos baixos das florestas neotropicais. Neste trabalho descrevemos os frutos consumidos pela rendeira (Manacus manacus) amostrados durante dois anos de estudo sobre o comportamento de forrageamento desta espécie em plantas frutíferas, coletando sementes de fezes e regurgitos de indivíduos capturados em rede de neblina e coletando sementes em arenas de machos que fazem lek para atração de fêmeas em áreas de restinga do litoral sul do estado de São Paulo. Manacus manacus consumiu 58 espécies de frutos de 30 famílias de plantas. Os frutos foram retirados a $3.5 \pm 1.9 \mathrm{~m}$ de altura do solo e $1.5 \pm 1.6 \mathrm{~m}$ abaixo do dossel florestal usando principalmente as manobras dos tipos sally-strike (retirada de frutos em voos curtos) e glean (retirada de frutos quando pousados em galhos). A maioria dos frutos eram bagas com diâmetros entre 3.1 a $17 \mathrm{~mm}$ e 1 a 86 sementes. Frutos com diâmetro até $12 \mathrm{~mm}$ foram engolidos inteiros. Frutos maduros e imaturos foram igualmente consumidos. Nossos resultados corroboram com a alta variedade de pequenos frutos consumidos por espécies de tangarás e indicam que M. manacus é um importante dispersor de sementes, sendo potencialmente importante para o recrutamento nas comunidades de plantas na restinga.

Palavras-chave: dispersão, frutos, interação animal-planta, sementes. 


\section{Introduction}

Most woody plants rely on frugivores to disperse their seeds in tropical forests (Gentry 1982). The number of fruit species consumed, the patterns of fruit removal, and the seed treatment given by a frugivore may influence seed dispersal effectiveness, and, ultimately, plant recruitment (Schupp 1993, Schupp et al. 2010). Manakins (Pipridae) are small frugivorous passerines abundant in the understory of primary and secondary neotropical forests (Blake \& Loiselle 2002, Loiselle et al. 2007). Manakins have broad diets, eating whole a great variety of small fruits, thus potentially exerting important role as seed dispersers (Worthington 1982, Blake \& Loiselle 2002, Snow 2004).

In restinga forests in southeastern Brazil, an ecosystem associated to the Atlantic forest biome, the White-bearded Manakin Manacus manacus (Linnaeus, 1766) is one of the most common passerines. In the present study, our objective is to describe the fruit diet and fruit consumption behavior of M. manacus in well-preserved patches of restinga forests in the southern portion of São Paulo state. More specifically, we assessed: (1) the number of plant species whose fruits were eaten by M. manacus, (2) the ripeness and biometrics of these fruits, and (3) the fruit removal manoeuvres and fruit handling techniques used by M. manacus. We suggest that the broad frugivorous diet of $M$. manacus contribute to the dispersal and recruitment of a variety of plants in restinga forest, which is nowadays heavily impacted by urbanization (Sampaio 2005).

\section{Material and Methods}

\section{Study area}

The study was conducted in the lowland forests of Itanhaém $\left(24^{\circ}\right.$ 10 ' 11.9" S and $\left.46^{\circ} 55^{\prime} 32.81^{\prime \prime} \mathrm{W}\right)$, Peruíbe (24 $15^{\prime} 10.81^{\prime \prime} \mathrm{S}$ and $46^{\circ}$ $55^{\prime} 16.94$ " W), and Juréia Itatins Ecological Station (Iguape, $24^{\circ} 28^{\prime}$ 07.4" S and $47^{\circ} 07^{\prime} 13.17$ "W), in the state of São Paulo, southeastern Brazil. The regional climate is subtropical and humid. Mean annual rainfall is 2,278 $\mathrm{mm}$ with the rainy season occurring from October to April, and the dry season from May to September. Mean annual temperature is $21.4^{\circ} \mathrm{C}$, with maximum and minimum temperatures averaging $25.8^{\circ} \mathrm{C}$ and $19.0^{\circ} \mathrm{C}$, respectively (Tarifa 2004). Study areas are still predominantly covered by restinga, a structurally simple vegetation composed by halophytic herbs and shrubs growing in the vicinity of the sea, and more complex vegetation in lowland and lower mountain forests as one moved further into the continent (Sampaio 2005). The most speciose plant families in the region are Myrtaceae, Leguminosae, Rubiaceae, Melastomataceae, Lauraceae, and Annonaceae (Mamede et al. 2004). The bird community of the region includes 314 species. Tanagers (Thraupidae) and flycatchers (Tyrannidae) are the most speciose bird families (Develey 2004).

\section{Bird species}

Manacus manacus is a small frugivorous (15-18 g weight; $8 \mathrm{~cm}$ wide gape size) and lekking passerine from lowland forests in the Neotropics. It has a widespread geographic distribution from Colombia to NE Argentina, inhabiting continuous and fragmented Amazonian and Atlantic forests in Brazil (Sick 1997, Snow 2004). In restinga, M. manacus is one of the most common manakin species (other common species is the Swallow-tailed Manakin Chiroxiphia caudata). It is sympatric with nearly 76 frugivorous bird species (C. C., pers. obs.). Secondary forests with high abundance of fruits are the preferred habitat of M. manacus (Snow 1962). Resident males of this species concentrate in lek areas composed by 2 to 70 oval courts of $0.15-0.9 \mathrm{~m}$ in diameter set on the ground of the forest wherein they display individually to attract potential mates (Snow 1962).

\section{Data collection}

To describe the diet of $M$. manacus, we conducted direct observations of its foraging behavior on plant species, collected seeds from feces and regurgitations of mist-netted individuals from April 2009 to March 2011, and collected seeds in 21 courts used by resident males in five lek areas from March 2010 to February 2011 in Itanhaém, Peruíbe, and Iguape municipalities. The foraging behavior of $M$. manacus was characterized considering the height of the fruits eaten, the foraging manoeuvres according to Remsen Junior \& Robinson (1990), and the fruit handling behavior (fruits swallowed whole or piecemeal). Considering that manakins may take several fruits during a feeding bout, we recorded only the first feeding event of individuals to quantify the species' foraging behavior. Characteristics of the fruit species such as fruit type, ripeness (assessed visually by inspecting their coloration and consistency: greenish and harder fruits were considered unripe; yellowish, darkish, and softer fruits were considered ripe), length and width (measured with a digital caliper), and number of seeds were accessed in the field. Mist-netted individuals were kept in cages with foam-lined walls for $30 \mathrm{~min}$ before being released, and all spontaneous regurgitated or defecated seeds collected within this period were considered a sample. Seeds collected on courts and its immediate vicinity $\left(0.70 \mathrm{~m}^{2}\right.$ of total sampled area per court) were accumulated monthly to a final number of species per court. We considered these seeds as most likely regurgitated and defecated by M. manacus due the substantial time that they spent near their courts (see Cestari 2010, Cestari \& Pizo 2012), although we cannot discard the possibility that some of the seeds have been deposited by other frugivores. All the seeds were identified to the lowest taxonomic level possible by comparison with a reference collection assembled during the study, and also consulting the literature and specialists. We followed the botanical nomenclature from Missouri Botanical Garden's eletronic databases (www.tropicos.org).

\section{Data analyses}

We evaluated the degree of completeness of the fruit sampling in the diet of M. manacus by plotting accumulation curves of plant species consumed according to each of the methods employed to sample diet.

The monthly frequency of feeding events on ripe and unripe fruits by $M$. manacus was compared using Wilcoxon test. We employed Bioestat 5.0 (Ayres et al. 2004) for all analyses. Significance was accepted at $P \leq 0.05$.

\section{Results}

Manacus manacus consumed fruits of 49 plant species which were taken at $3.5 \pm 1.9 \mathrm{~m}$ height (range: $0.2-9 \mathrm{~m} ; N=194)$ and $1.5 \pm 1.6 \mathrm{~m}$ below the forest canopy (range: $0-6.5 \mathrm{~m}$ ). Birds frequently used sally-strike (59\% of foraging manoeuvres, $N=194$ ) and glean (35\%) manoeuvres to take fruits, followed by reach $(4 \%)$ and sally-hover $(2 \%)$. Fruits were preferentially swallowed whole $(89 \%)$. There was no difference in monthly frequency of ingestion of ripe (54\% of feeding bouts) and unripe fruits $(46 \%)(\mathrm{Z}=0.62$, $d f=24, P=0.53$; Figure 1). Seeds from 21 plant species were recorded from birds held in cages, while 45 species were collected below courts of male manakins. Overall, M. manacus consumed fruits (mainly of the berry type) of 58 plants species and 30 plant families that contained from 0 to 86 seeds, and varied from 3.1 to $12 \mathrm{~mm}$ in diameter (Table 1). Species accumulation curves revealed that new species might be added to our sampling (Figure 2). Myrtaceae (10 spp.), Melastomataceae (5 spp.), and Rubiaceae were the most consumed plant families. 
Frugivory by White-bearded Manakin (Manacus manacus)

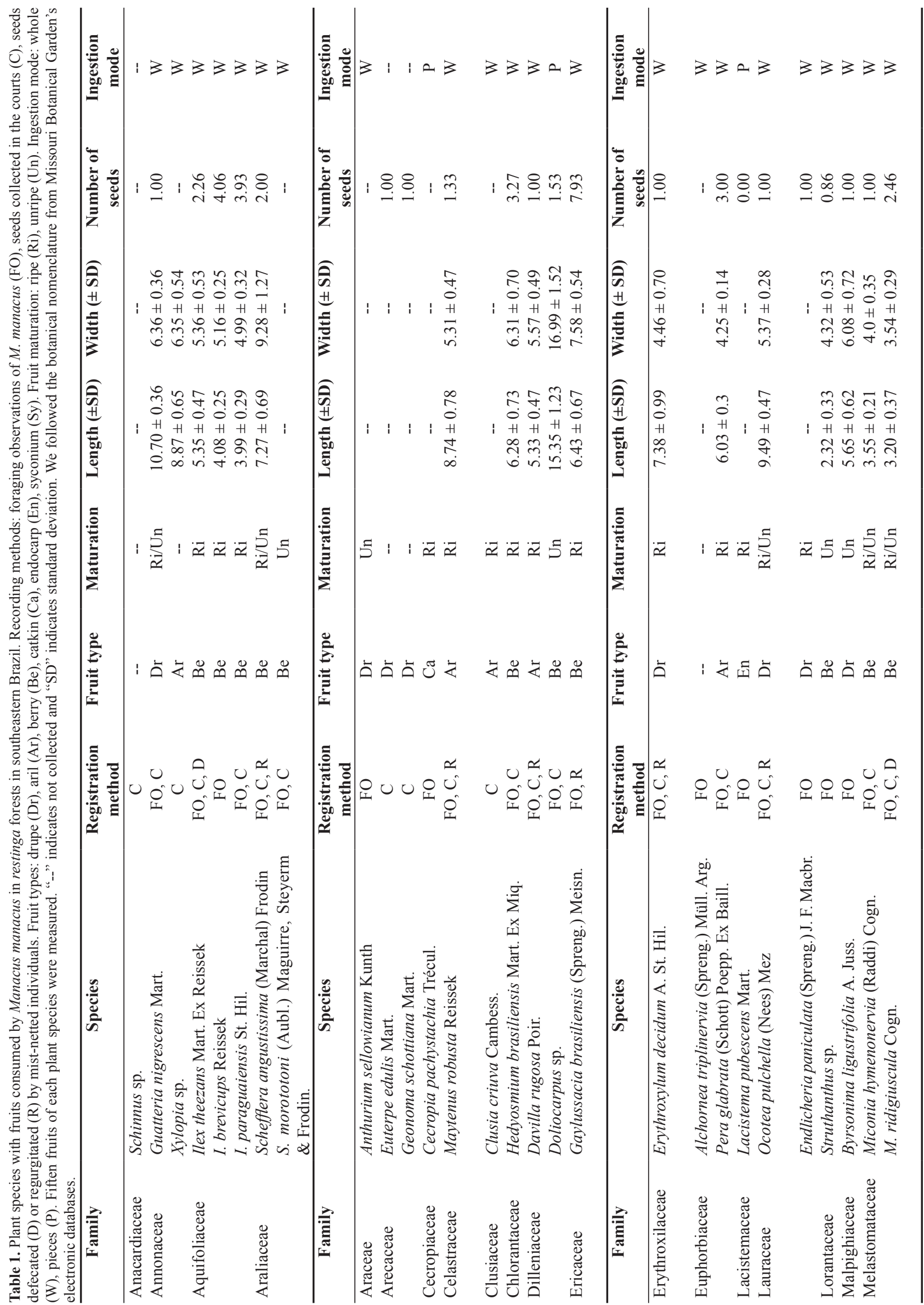


Cestari, C. \& Pizo, M.A.

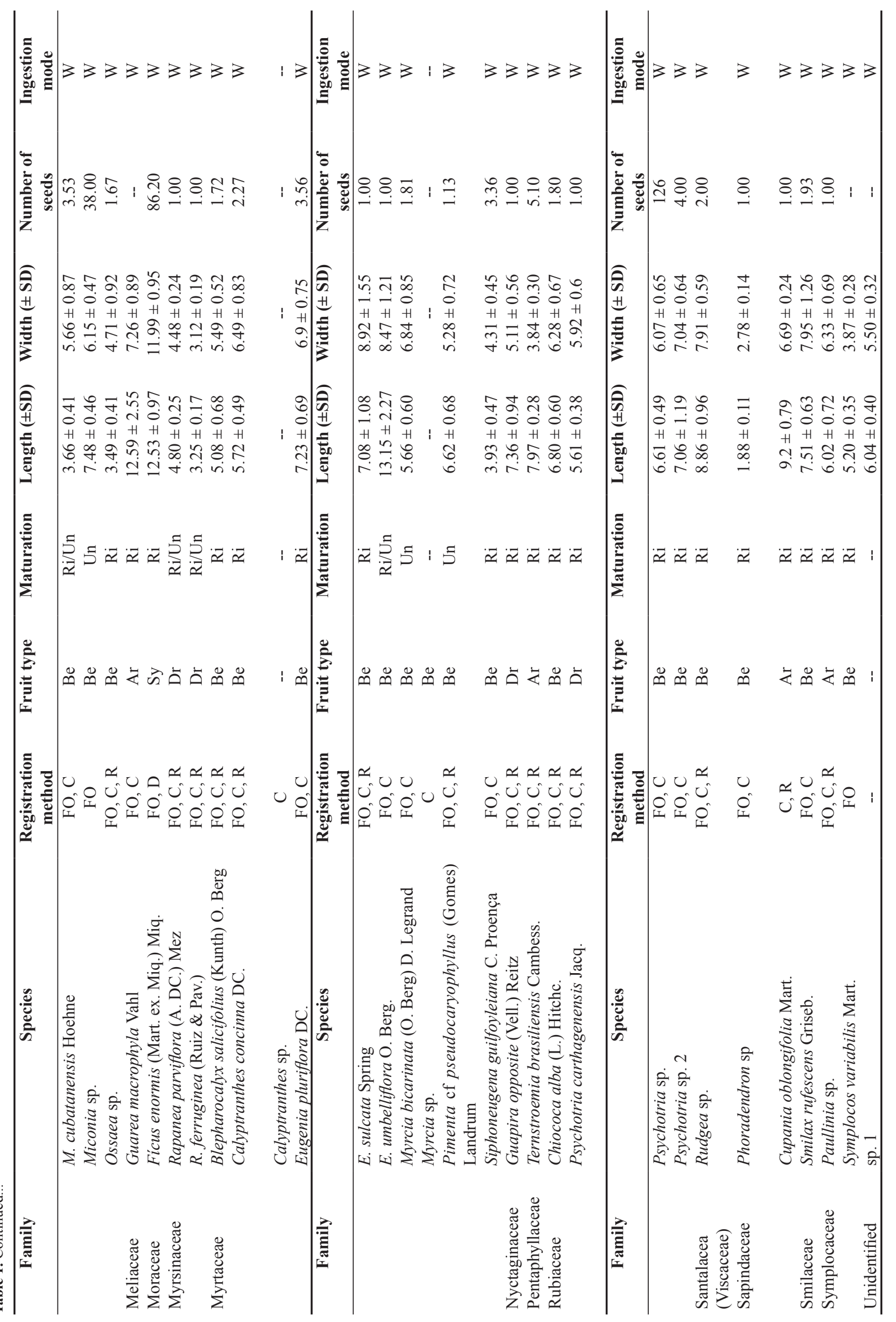




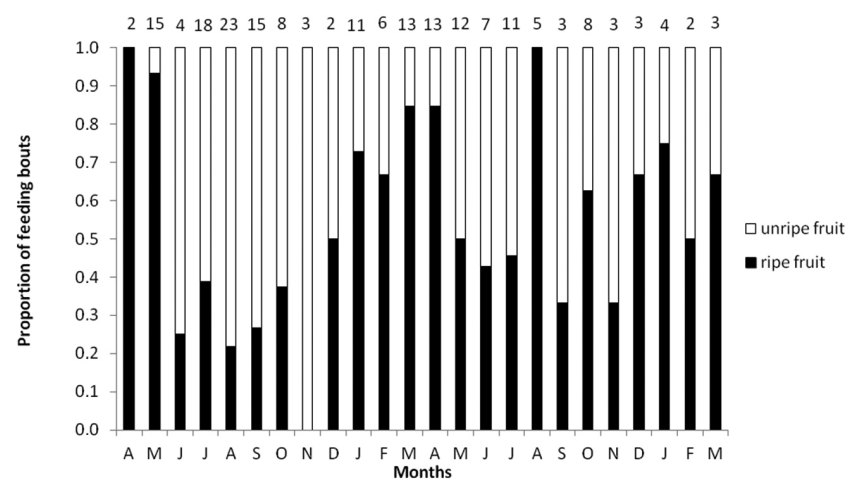

Figure 1. Monthly proportion of feedings on ripe and unripe fruits by Manacus manacus in restinga forests from southeastern Brazil. Data were collected from April 2009 to March 2011. Numbers above bars indicate the total number of feeding events at each month.

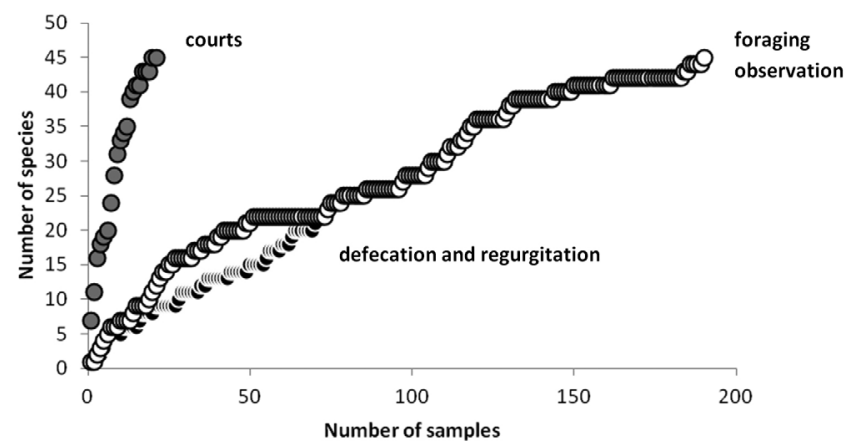

Figure 2. Accumulation curves of the number of plant species eaten by Manacus manacus in restinga forests from southeastern Brazil. Samples vary according to the method used (i.e., number of plants observed during bird foraging observations, number of defecations or regurgitations collected from caged birds, and number of courts inspected for seeds).

\section{Discussion}

Although forests may differ markedly in plant species diversity and researchers may use different sampling methods to collect data on bird diets, our results focused on the fruit diet of M. manacus in restinga forests corroborated data from other studies that showed a great variety of fruits consumed by manakin species in the understory of neotropical forests. We recorded 58 species of plants consumed by $M$. manacus and more plant species will likely be added if we continued sampling. Snow (1962) recorded 105 species of fruits consumed by M. manacus in Trinidad Island. Worthington (1982) recorded at least 62 species of plants whose fruits were fed by Goldencollared Manakin Manacus vitellinus (Gould, 1843) and Red-capped Manakin Pipra mentalis (P.L. Sclater, 1857) in Barro Colorado Island. Loiselle et al. (2007) recorded seeds of 70 and 39 plant species in feces of $P$. mentalis and White-ruffed Manakin Corapipo altera (P.L. Sclater, 1863), respectively, in Costa Rica, plus seeds of 49 plant species in feces of Blue-crowned Manakin Lepidothrix coronata (Spix, 1825), 27 plant species for Golden-headed Manakin Pipra erythrocephala (Linnaeus, 1758), 33 plant species for Wire-tailed Manakin P. filicauda (Spix, 1825), and 44 plant species for Whitecrowned Manakin P. pipra (Linnaeus, 1758) in Ecuador.

Manacus manacus and other manakins have a wide gape in relation to their body size, which allows them to swallow whole fruits that cannot be swallowed by larger birds such as some tanagers (Snow 1962). In our study, M. manacus had no difficult to swallow fruits up to $12 \mathrm{~mm}$ width; fruits up to $16 \mathrm{~mm}$ width (e.g., Coussarea paniculata M. Vahl Standl.) were swallowed by this species in Trinidad (Snow 1962). Manacus manacus was also recorded consuming all types of available fruits, including unripe ones. According to Levey (1987a), the less rigorous fruit selection by manakins may be a consequence of their fruit-handling technique and foraging manoeuvres that enable them to swallow fruits whole in such a way that does not permit the detection of fruit taste once birds rarely come into contact with any part of a fruit except skin surface. Additionally, manakins apparently do not suffer negative effects of toxic secondary compounds usually present in unripe fruits. Foster (1977) recorded a high frequency of unripe fruits eaten by the Long-tailed Manakin (Chiroxiphia linearis) during a period of fruit scarcity in Costa Rica, and detected no difference in the body mass of individuals between periods of normal availability and scarcity of ripe fruits.

From the bird's perspective, the gulper behavior of manakins may be disadvantageous because birds accumulate seeds in their guts (Levey 1987b). However, because their high metabolic rate (see Barske et al. 2011), studies indicated that some manakins (including Manacus spp.) evolved behavioral and physiological adaptations such as rapid passage of fruits (and seeds) through their guts, high assimilation of nonstructural carbohydrates, selective regurgitation, and rapid elimination of bulky seeds that allow them to ingest a high rate of fruits compared to larger birds (see Worthington 1989). In another study, we estimated an average of four defecations (or regurgitations) containing 1.3 seeds per defecation (or regurgitation) at each $5 \mathrm{~min}$ (Cestari \& Pizo 2013 ). This defecation rate is relatively high even compared with other manakin species (Worthington 1989).

In conclusion, the consumption of fruits of a great variety of plant species and, judging by other manakin species (Loiselle et al. 2007), the gentle treatment of ingested seeds makes M. manacus a prominent seed disperser in restinga forests, an ecosystem often degraded by urban expansion for which restoration efforts are urgently needed. As an abundant species that disperse a variety of seeds and move widely through restinga forests (Cestari \& Pizo 2013), M. manacus is an important helper of restoration efforts.

\section{Acknowledgements}

We are grateful to Ílson L. Prado, Rubens R. do Prado, Sr. Plínio and all the staff of Juréia Ecological Station. We thank Rodrigo Tsuji for helping in identification of plant species and two anonymous reviewers. CC and MAP receive research grants from the Brazilian Research Council (CNPq). FAPESP (proc. No. 2009/17577-3) provided financial support to buy materials used on the field. CAPES (proc. No. 9729-11-9) supported the stay of CC in USA as part of $\mathrm{PhD}$ sandwich program.

\section{References}

AYRES, M.M., AYRES, J.R., AYRES, D.L. \& SANTOS, A.S. 2004. BioEstat 5.0: Aplicações estatísticas nas áreas das ciências biológicas e médicas. Sociedade Civil Mamirauá, MCT-CNPq, Conservation International, Belém.

BARSKE, J., FUSANI, L., WIKELSKI, M. \& SCHLINGER, B. 2011. Heart rate as an index of increased metabolic output in a bird with a complex courtship display. Integr. Comp. Biol. 51(suppl 1):e6.

BLAKE, J.G. \& LOISELLE, B.A. 2002. Manakins (Pipridae) in secondgrowth and old-growth forests: Patterns of habitat use, movement, and survival. Auk 119(1):132-148.

CESTARI, C. 2010. Anting behavior by the White-bearded Manakin (Manacus manacus, Pipridae): na example of functional interaction in a frugivorous lekking bird. Biota Neotrop. 10:339-342. http://dx.doi.org/10.1590/ S1676-06032010000400038 
CESTARI, C. \& PIZO, M.A. 2012. Lek phenology of the White-bearded Manakin (Manacus manacus, Pipridae) in a subtropical region. J. Nat. Hist. 46:2999-3009. http://dx.doi.org/10.1080/00222933.2012.727485

CESTARI, C. \& PIZO, M.A. 2013. Seed dispersal by the lek-forming whitebearded manakin (Manacus manacus, Pipridae) in the Brazilian Atlantic forest. J. Trop. Ecol. In press.

DEVELEY, P. 2004. As aves da Estação Ecológica Juréia-Itatins. In Estação Ecológica Juréia-Itatins. Ambiente físico, flora e fauna (O.A.V. Marques \& M. Duleba, eds.). Holos, Ribeirão Preto, p.278-295.

FOSTER, M.S. 1977. Ecological and nutritional effects of food scarcity on a tropical frugivorous bird and its fruit source. Ecology 58(1):73-85. http:// dx.doi.org/10.2307/1935109

GENTRY, A.H. 1982. Patterns of neotropical plant-species diversity. Evol Biol. 15:1-85. http://dx.doi.org/10.1007/978-1-4615-6968-8_1

LEVEY, D.J. 1987a. Sugar-tasting ability and fruit selection in tropical fruiteating birds. Auk 104:173-179.

LEVEY, D.J. 1987b. Seed size and fruit-handling techniques of avian frugivores. Am. Nat. 129(4):471-485. http://dx.doi.org/10.1086/284652

LOISELlE, B., BLENDINGER, P.G., BLAKE, J. \& RYDER, T.B. 2007. Ecological redundancy in seed dispersal system: a comparison between manakins (Aves:Pipridae) in two tropical forests. In: Seed dispersal: theory and its application in a changing world. (A.J. Dennis, E.W., Schupp, R., Green, \& D.W. Westcott, eds.). CABI Publishing, Wallingford, p.178-195.

MAMEDE, M.C.H., CORDEIRO, I., ROSSI, L., MELO, M.M.R.F. \& OLIVEIRA, R.J. 2004. Mata Atlântica. In Estação Ecológica JuréiaItatins. Ambiente físico, flora e fauna (O.A.V. Marques \& M. Duleba, eds.). Holos, Ribeirão Preto, p.115-132.
REMSEN JUNIOR, J.V. \& ROBINSON, S.K. 1990. A classification scheme for foraging behavior of birds in terrestrial habitats. Stud. Avian Biol. 13:144-160.

SAMPAIO, D. 2005. Restinga. In Árvores da restinga: guia de identificação (D. Sampaio, V.C. Souza, A.A. Oliveira, J., Paula-Souza \& R.R. Rodrigues, eds). Neotrópica, São Paulo, p.25-30.

SCHUPP, E.W. 1993. Quantity, quality and the effectiveness of seed dispersal by animals. Vegetatio 108(1):15-29.

SCHUPP, E.W., JORDANO, P. \& MARIA GOMEZ, J. 2010. Seed dispersal effectiveness revisited: a conceptual review. New Phytol. 188:333-353. PMid:20673283. http://dx.doi.org/10.1111/j.1469-8137.2010.03402.x

SICK, H. 1997. Ornitologia Brasileira. Nova Fronteira, Rio de Janeiro.

SNOW, D. 1962. A field study of the Black and White Manakin, Manacus manacus, in Trinidad. Zoologica. 47:65-104.

SNOW, H. 2004. Family Pipridae (Manakins). In Handbook of the Birds of the World: Cotingas to Pipits and Wagtails. (J. del Hoyo, A., Elliot \& D.A. Christie, eds). Lynx Editions, Barcelona, p.110-169.

TARIFA, J.R. 2004. Unidades climáticas dos maciços litorâneos da JuréiaItatins. In Estação Ecológica Juréia-Itatins. Ambiente físico, flora e fauna (O.A.V. Marques \& M. Duleba, eds). Holos, Ribeirão Preto, p.42-50.

WORTHINGTON, A. 1982. Population size and breeding rhythms of two species of manakins in relation to food supply. In The ecology of a tropical forest: reasonal rhythms and long-term changes (E.G. Leigh Junior, A.S. Rand \& D.M. Widson, eds). Smithsonian Institution Press, Washington, p.213-225.

WORTHINGTON, A.H. 1989. Adaptations for avian frugivory: assimilation efficiency and gut transit-time of Manacus vitellinus and Pipra mentalis. Oecologia 80:381-389. http://dx.doi.org/10.1007/BF00379040 